\title{
Money In Modern Macro Models: A Review of the Arguments
}

\author{
Franz Seitz ${ }^{1, *}$ and Markus A. Schmidt ${ }^{2}$ \\ ${ }^{1}$ Weiden Technical University of Applied Sciences, WSB Poznan, Hetzenrichter Weg 15, D-92637 Weiden, \\ Germany \\ ${ }^{2}$ Deutsche Bundesbank, Wilhelm-Epstein-Str. 14, 60431 Frankfurt am Main, Germany
}

\begin{abstract}
This paper provides an overview of the role of money in modern macro models. In particular, we are focussing on New Keynesian and New Monetarist models to investigate their main findings and most significant shortcomings in considering money properly. As a further step, we ask about the role of financial intermediaries in this respect. In dealing with these issues, we distinguish between narrow and broad monetary aggregates. We conclude that for theoretical as well as practical reasons a periodic review of the definition of monetary aggregates is advisable. Despite the criticism brought forward by the recent New Keynesian literature, we argue that keeping an eye on money is important to monetary policy decision-makers in order to safeguard price stability as well as, as a side-benefit, ensure financial market stability. In a nutshell: money still matters.
\end{abstract}

Keywords: Money, New Keynesian model, New Monetarist model, financial intermediaries.

"Money so they say, Is the root of all evil today."

(Pink Floyd)

\section{INTRODUCTION}

Since the formation of Stockholms Banco ${ }^{1}$ in 1656, safeguarding the value of money remained one of the main tasks of monetary authorities. Although this objective is widely accepted, disagreement persists on how to achieve a situation that is commonly referred to as "price stability". One of the most influential views on this issue is provided by the "quantity theory of money" whose modern version is established in economic theory since Friedman (1956). ${ }^{2}$ According to the quantity theory, there is a close link between the growth rate of money and the inflation rate - at least in the long run.

The implications of the quantity theory are known among researchers as well as policy-makers and empirical evidence in its favour is well-documented (e.g. Teles \& Uhlig, 2010). However, in parallel to monetary policy becoming increasingly based on theoretical models and empirical evidence (Mishkin,

*Address correspondence to this author at the Weiden Technical University of Applied Sciences, WSB Poznan, Hetzenrichter Weg 15, D-92637 Weiden, Germany; Tel: +49-961-382-1318; Fax: +49-961-382-2318;

E-mail: f.seitz@oth-aw.de

JEL Classification Numbers: E51, E52, E58.

\footnotetext{
${ }^{1}$ Stockholms Banco is the predecessor of Sveriges Riksbank which is considered the world's oldest central bank today.

${ }^{2}$ The quantity theory of money is one of the oldest and best-known principles in economics. Irving Fisher (1911) gave a definitive statement of the classical approach to monetary economics. However, considerations on the link between money and prices date back to the British philosopher John Locke (* $1632, \dagger 1704)$
}

2010, 81) money's information content for monetary policy got more and more into doubt. In particular, owing to the seminal works by Kydland \& Prescott (1982) and Long \& Posser (1983), Real Business Cycle (RBC) and recently Dynamic Stochastic General Equilibrium (DSGE) models gained importance for monetary policy purposes. Despite these models' theoretical appeal, they have still not been able to adequately explain money and money only plays a passive role in them, if at all (see section 3 ).

The neglect of money in monetary policy decisions seems to have come to an end since the dawn of the financial crisis in 2007. After the break-out of the crisis, it was realised that looking at monetary developments would have signalled the built-up of financial imbalances at an early stage (Borio \& Lowe, 2002). Moreover, since central banks around the world conduct quantitative easing ${ }^{3}$ in order to counteract the negative consequences of the financial market tensions for the real economy, money re-gained prominence on the monetary policy agenda. At the same time, with central banks flooding the banking system with liquidity, concerns increased that this huge liquidity provision will cause inflation to accelerate in the future.

Thus, there seems to be an obvious contradiction between state-of-the-art economic theory and the

\footnotetext{
${ }^{3}$ Quantitative easing is the central bank policy to increase liquidity in the economy when interest rates are near zero by buying assets (e.g. Government bonds). This first of all increases bank reserves (the monetary base). In a second step, this policy is expected to also increase the money stock in the hands of the public.
}

E-ISSN: $1929-7092 / 14$
(C) 2014 Lifescience Global 
conduct of monetary policy in practice in recent times. Indeed, this has left observers and policy makers somewhat confused about money's actual relevance for economic developments in general and monetary policy in particular. This paper aims at resolving this confusion. The remainder is structured as follows: First, in the second section, we provide some general reflections on the role of money, shedding light on money by itself and its use in theoretical and practical applications. By doing so, we identify some misunderstandings and inadequateness of many macro models, which, to our opinion, provide a reason for these models' inability to justify a non-trivial role for money as yet. The third section concentrates on the canonical workhorse model now in use, the New Keynesian (NK) model, putting particular emphasis on the different theoretical approaches that have been employed to introduce money into these models. In section four we switch to a newer research agenda, the so-called New Monetarist (NM) approach. While NK models usually conclude that there is only a trivial role for money in the economy, the NM literature claims that money facilitates transactions that otherwise would not have taken place. Despite that, NM models seem far from providing a generally accepted toolbox for the investigation of money. We provide some rationale for why this is actually the case. The fifth part deals with an aspect of money that is often neglected in modern macro models, namely financial intermediation. In our opinion, considering financial intermediation is essential when dealing with money and trying to understand the interaction between price stability and financial stability. Taking financial intermediaries explicitly into account thus allows addressing monetary policy and macro-prudential issues simultaneously. Finally, section six concludes and provides some implications for monetary analysis.

\section{SOME GENERAL REFLECTIONS}

One buck is like another, isn't it? Actually, it's not! Talking about money necessitates a clear distinction between different types of money. The most fundamental one is that between inside and outside money (see, e.g., Lagos, 2006). ${ }^{4}$ Of course, the liquidity provision of a central bank to its counterparties

\footnotetext{
${ }^{4}$ Inside money is a debt as well as an asset held by the private sector (e.g. demand deposits at banks). Outside money, in contrast, is a debt of the government (including the central bank), while it is an asset of the private sector (e.g. cash or the monetary base). The distinction between inside and outside money goes back to Gurley \& Shaw (1960). The idea that financial intermediation is essential for understanding monetary developments is already referred to in Brunner \& Meltzer (1966).
}

- conducted via so-called outside money - does not necessarily affect consumer prices. It might only have inflationary consequences in case it will be transformed into potentially inflation-relevant inside money via commercial banks' granting of credit to the moneyholding sector. Unfortunately, many theoretical models do not explicitly distinguish between outside (or base) money and inside money. Indeed, money and credit are linked via the money-issuing sector's ${ }^{5}$ (consolidated) balance sheet (see Figure 1). Thus, an expansion of base money might fuel an increase in bank lending to the money-holding sector, which in turn could result in an expansion of the stock of (inside) money. This transmission channel, however, is rather indirect. There might even be reverse causality. This leads us to the conviction that theoretical approaches should either model the transmission of outside into inside money explicitly or should - as a minimum requirement - be explicit on the definition of money that is actually used.

Even though (inside) money might technically be linked to credit via the balance sheet identity and despite the fact that many modern macro models explicitly deal with credit (see section 3) or investigate money's role in facilitating trade (see section 4), there is no formal and generally accepted micro-founded (general equilibrium) theory of money as yet. Such a theory should be able to explain how money arises endogenously, why money is preferred to other means of transaction and how welfare is enhanced by the existence of money (Thornton, 2000, 35).

\begin{tabular}{l|l} 
Assets & \multicolumn{1}{c}{ Liabilities } \\
\hline $\begin{array}{l}\text { Credit to general government } \\
\text { Loans }\end{array}$ & Currency in circulation \\
Securities & Overnight deposits \\
Credit to private sector & Other short-term deposits \\
Loans & Marketable instruments \\
Securities & Holdings of general government \\
Net claims on non-residents & Longer-term liabilities \\
Shares \& other equity & Remaining liabilities \\
Remaining assets &
\end{tabular}

Figure 1: A stylised MFI balance sheet.

Most monetary macro models highlight money's unique role for transactions purposes. They thus interpret the facilitation of trade, the lowering of trading

\footnotetext{
${ }^{5}$ In the euro area, Monetary Financial Institutions (MFIs) constitute the moneyissuing sector. They consist of central banks, commercial banks, money market funds and building societies.
} 
frictions (e.g., by lowering problems associated with asymmetric information) as well as the reduction of transaction costs as money's essential functions. ${ }^{6}$ Concentrating on trade, however, implies that models dealing with representative agents' models are not well-suited to capture money's importance, since there is no rationale for trade between identical individuals. Instead, heterogeneous agents' models should be in the focus and all approaches based on homogeneous agents thus seem to be subject to a fundamental shortcoming. ${ }^{7}$

In theoretical frameworks, the importance of money for transactions in goods and services might partly relate to the fact that the ultimate goal of monetary policy in these frameworks is price stability and/or stabilising the output gap. Even though this is thus in line with reality, the interpretation of the transmission channel from monetary developments to inflation inherent in this view might be too narrow. In fact, monetary policy practice since the end of the 1980s relied more and more on broader monetary aggregates, so its scope was actually beyond pure transaction-oriented definitions.

Theoretical models' emphasis on money's role as a means of transaction does also result in an inaccuracy frequently perpetrated in empirical applications: Therein, researchers usually employ a narrow money concept, commonly $\mathrm{M} 1$, in analysing money's role in economic developments. Doing so, however, should not be interpreted as the central bank having perfect control over M1, which is actually not the case. If at all, the central bank is able to indirectly steer the quantity of money by adjusting the monetary base or short-term interest rates. Since the transmission and intermediation process from the monetary base to inside money is complex and time-varying (see already, e.g., Brunner and Meltzer, 1966), perfect controllability of whatever monetary aggregate might be too much of a simplification and could thus result in misguided conclusions.

An additional aspect of money that is often left out of consideration in both theoretical macro models and empirical investigations is its use in financial market transactions. In fact, money's disposition is not limited

\footnotetext{
${ }^{6}$ For King (2002), the proof of a significant role for money for real developments has to be based on the two observations that money reduces transactions costs and that transactions costs are important in determining (asset) prices.

${ }^{7}$ Some authors even suggest that monetary exchange should be analysed in an environment characterized by specialized traders, see Alchian (1977), Howitt (2005) and Krueger (2012).
}

to transactions in goods and services. Money also enables agents to purchase financial assets, many of which, though interest-bearing, are not held for investment purposes in the first place, but for liquidity reasons. These short-term interest-bearing assets are available for financing transactions in the not-toodistant future and are thus a possible source of price pressure in case this potential demand for goods and services materialises.

Against this background, it seems obvious to broaden the interpretation of money, since it might be a too restrictive view to solely emphasise money's role as a means of transaction. Rather, the above-mentioned considerations call for a broad monetary aggregate as the appropriate measure of money like M2 or M3 in the Eurosystem. ${ }^{8}$

Nevertheless, many empirical investigations of standard money-demand functions using broad monetary aggregates in the euro area have documented a large and persistent residual, at least since 2004 (see Figure 2). This finding has been frequently interpreted as an indication that the moneydemand specification collapsed which led both academic mainstream as well as policy makers to conclude that money cannot be assigned a central role for monetary policy purposes (Woodford, 1998; Reichlin, 2006). ${ }^{9}$ Subsequently, much effort was spent in trying to counter this critique and re-specify the money demand function by augmenting it with various additional variables, e.g. stock market, housing market or uncertainty variables (see, among others, Greiber \& Lemke, 2005, and Greiber \& Setzer, 2007) or to introduce non-linearities (see, e.g., Dreger \& Wolters, $2010)$ into the basic specification. However, against the background of the experiences the euro area made since the dawn of the financial crises, one might conclude that the observed persistent error term in the standard money demand specification could have indicated the build-up of an imbalance with potentially severe consequences. Thus, investigating its causes could probably be helpful in identifying, understanding and explaining financial crises. ${ }^{10}$

\footnotetext{
${ }^{8}$ In the Eurosystem's definition of monetary aggregates, M3 comprises M1 (currency in circulation and overnight deposits), other short-term deposits (short-term saving deposits and short-term time deposits which together with M1 sum-up to M2) and marketable instruments (repurchase agreements, money market fund shares, short-term debt securities).

${ }^{9}$ However, Canova and Ferroni (2011) show that the role of money may be underestimated in empirical analyses due to choosing an inappropriate statistical filter.

${ }^{10}$ One might even argue that money demand is by definition stable as instability is only due to omitted variables.
} 


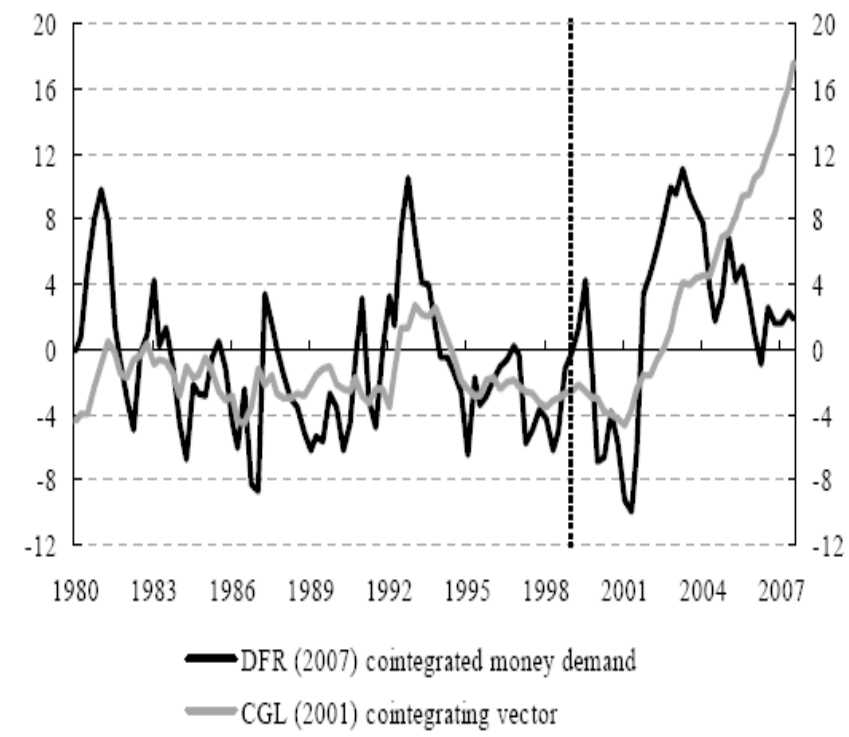

Figure 2: Residual of a standard money demand specification based on Calza et al. (2001) and de Santis et al. (2013).

In fact, this view leads us to a commonly encountered mis-conception regarding the money inflation link in today's general equilibrium (GE) macro models: Actually, this link is neither direct (Nelson, 2003) nor is it an equilibrium concept. In contrast, risks to price stability emerge in disequilibria only. But even if this disequilibrium is identified, the inflationary risk does not necessarily materialise. ${ }^{11}$ Of course, there are factors that temporarily have the potential to induce agents holding more (or less) money than they would usually need in order to finance their demand for goods and services. Among these are variations in the velocity of money, uncertainty or developments in asset prices. In addition, it is not necessarily the case that any disequilibrium adjusts via price movements in goods markets, which are in the focus of the usual definition of inflation. In fact, the adjustment can also take place via asset prices, i.e. financial market imbalances. Consequently, Nelson (2003) highlights that the quantity theory neither claims a direct link between money and inflation nor does it rest on that interpretation. In fact, money is seen to be one factor determining real aggregate demand relative to potential output. Thus, Nelson argues that in empirical investigations of the Phillips curve, a significant coefficient on money rather indicates measurement

\footnotetext{
${ }^{11}$ As Milton Friedman put it: "What would it mean for money of itself to drive up prices? What drives up prices is spending by the holders of money, driven by many factors, of which the quantity of money that they happen to have at the moment is one." (Nelson, 2003, 1040). Similarly, Brunner $(1969,26)$ states: "Of course, it is not money as such which drives up prices."
}

errors or a misspecification of the IS-curve once the output gap is taken into account. ${ }^{12}$

A growing literature supports the view that monetary analysis can help ex-ante to identify the build-up of financial imbalances. ${ }^{13}$ For example, Alessi \& Detken (2011) find that analysing monetary developments provides useful information for detecting financial market misalignments and financial market crises arising from these. In a similar vein, Adrian \& Shin (2011) show theoretically the importance of financial intermediaries' balance sheet quantities as an indicator for financial market participants' risk appetite. ${ }^{14}$ Importantly, as Adalid and Detken (2007) conclude, the empirically convincing indicator properties of money for the build-up of financial imbalances are usually not only found for narrow, but for broad monetary aggregates as well. Moreover, this conclusion holds true for both the global and the country-level. As regards this financial stability dimension of money, its role goes beyond the pure transactions motive and emphasises store-ofvalue and precautionary considerations. ${ }^{15}$

Having in mind all the above-mentioned arguments regarding the link between money and credit, the merits of broad monetary aggregates and the benefits money (and credit) provides for detecting financial market imbalances, another shortcoming of state-ofthe-art macro models becomes obvious: The modelling of a banking sector. Whenever a banking sector is explicitly taken into account in modern theoretical approaches, this is usually done in order to model credit rather than because they aim at modelling money (see, e.g., Adrian \& Shin, 2011; Gertler \& Kiyotaki, 2011). ${ }^{16}$ On the one hand, concentrating on credit omits money's role for funding banks' granting of credit. On the other hand, it neglects the fact that a credit economy would in any case give rise to money

\footnotetext{
${ }^{12}$ This statement must not be confounded with the well-known Goodhart's law (Goodhart, 1975a, b), which states that once monetary policy reacts to a specific economic variable, this particular variable will become insignificant in empirical investigations.

${ }^{13}$ See for a broad range of countries and a sample of more than one century Schularick \& Taylor (2012).

${ }^{14}$ In this direction, intertemporal risk smoothing (related to financial intermediaries' creation of informationally insensitive deposits) implies to only include deposits of commercial banks (besides currency) in monetary aggregates, but no marketable securities. Moreover, as financial market crises often are liquidity crises and as the concept of money by definition has the highest degree of liquidity, money comes into play from this direction, too.

${ }^{15}$ In fact, empirical studies usually conclude that credit aggregates (the counterpart to money) also perform well or even better than monetary aggregates (see Gerdesmeier et al, 2010; Borio \& Lowe, 2002) in detecting asset price misalignments.

${ }^{16}$ However, if there arises a role for money in models which, in the first place, try to introduce credit, this would be even a stronger argument for looking at money.
} 
as a medium of exchange (Thornton, 2000, 51ff.). Credit promises are most efficient if they are denominated in the form of outside money, i.e. currency. But as long as the commitment of financial institutions to exchange deposits for cash immediately and at a fixed one-to-one nominal value is credible, these two forms of transactions money are perfect substitutes and should be included in the stock of money. Ultimately, this also means that models are not complete as long as money is missing.

Due to the balance sheet identity, modelling credit is often seen as being sufficient for capturing the effects of money for the macroeconomy. However, treating money and credit as perfect substitutes disregards many other important balance sheet items of monetary financial institutions, e.g. net-external assets or longerterm financial liabilities, as highlighted by Nelson (2008). In addition, shadow-banking activity and banks' off-balance sheet transactions can contribute to an increase in bank deposits but are not necessarily considered as a respective granting of credit (see Bernanke, 2008). Thus, Woodford (2008, section 2) rightly concludes that an emphasis on credit (frictions) should not be seen as a sufficient condition for rationalising a useful role of money.

\section{NEW KEYNESIAN MODELS}

Before discussing New Keynesian theory in more detail, it seems worth clarifying a fairly common misunderstanding: NK literature and the Monetarist view of a long-run relationship between money and inflation are not mutually exclusive. Many researchers working on NK theory do not support the view that money is unimportant to inflation. Actually, Woodford (at the ECB's 2006 central banking conference, see Reichlin, 2006) as well as Uhlig (2006) state that "we are all Monetarists now". NK literature, however, frequently doubts that there is a rationale for a prominent role for money in a central bank's monetary policy strategy.

\subsection{The Standard NK Model and its Implications for Monetary Policy}

The conclusion on money's irrelevance for monetary policy purposes can be derived from the typical setup of a New Keynesian (NK) model. NK-type models of this kind are nowadays frequently used to address monetary policy-related issues. They are based on a combination of an IS relationship, a Phillips curve as well as a policy rule determining jointly the real interest rate $(r)$, the output gap and the inflation rate (e.g. Clarida et al., 1999). The key friction that gives rise to short-run non-neutralities of monetary policy is - by assumption - price stickiness, i.e. a nominal rigidity. ${ }^{17}$ The central bank is viewed as being able to set a short-term nominal interest rate, and the policy problem is presented as a choice over alternative rules for how this should be done in response to economic conditions. The standard NK model in its basic form can be summarized by equations (1) - (3):

$$
\begin{aligned}
& x_{t}=-\phi_{i}\left(i_{t}-E_{t} \pi_{t+1}\right)+E_{t} x_{t+1}+\varepsilon_{t}^{x} \\
& \pi_{t}=\lambda_{x} x_{t}+\lambda_{\pi} E_{t} \pi_{t+1}+\varepsilon_{t}^{\pi} \\
& i_{t}=\omega_{0}+\omega_{x} x_{t}+\omega_{\pi} E_{t} \pi_{t+1}+\varepsilon_{t}^{i} \\
& \left(m_{t}-p_{t}\right)=\alpha_{0}+\alpha_{1} y_{t}-\alpha_{2} i_{t}+\varepsilon_{t}^{m}
\end{aligned}
$$

Equation (1) is the IS relation with $x$ the output gap, $i$ the nominal interest rate, $\pi$ the inflation rate and $E$ the (rational) expectation operator. (2) shows the AS relation (or alternatively the Phillips curve) according to which inflation depends positively on the output gap and expected inflation. (3) provides the Taylor-type monetary policy reaction function which closes the model. ${ }^{18}$ The $\varepsilon$ terms are $A D, A S$ and interest rate shocks, respectively. These three equations determine the three endogenous variables $x, \pi$ and $r$. Adding a money demand equation (4) to the above system does not affect the three variables of interest. The money demand function is redundant as it adds one unknown variable, i.e. money, and one equation identifying it in the system. As a consequence, steady-state inflation can be derived without considering money as it is represented by the credible inflation target of the central bank (Woodford, 2008). ${ }^{19}$ In fact, (4) just describes how money supply has to adjust in order to balance money demand. ${ }^{20}$ Causality runs, if at all, from

\footnotetext{
${ }^{17}$ An alternative strand of the NK literature, investigating the consequences of sticky information for economic developments, was introduced by Mankiw \& Reis (2002).

${ }^{18}$ It is worth noting that due to observational equivalence, interest rate behaviour following (3) is compatible with very different monetary policy rules including money supply rules, see Minford et al. (2002). Moreover, it is generally accepted that the central bank can (credibly) control (at least narrow) money, whereas (3) suggests that it can control (the whole term structure of) interest rates which is more at odds with common wisdom (see, e.g. Thornton, 2014).

${ }^{19}$ This procedure defines away the problem of establishing and maintaining central bank credibility.

${ }^{20}$ This conclusion would change if money enters one of the equations (1) - (3), see Canova \& Menz (2011). The standard NK model is also capable of describing the behaviour of a central bank steering money supply according to (4). In this case, the "Taylor rule" interest rate equation (3) becomes obsolete.
} 
prices to money and not the other way round. In particular, there is no role for money (shocks) in explaining short-run inflation dynamics, which are according to (2) solely determined by inflation expectations and the output gap. The output gap, in turn, is a function of real marginal costs' deviation from their steady state level and thus depends on expected output and the real interest rate (e.g. Clarida et al., 1999; Woodford, 2003). Given that there is no role for money in NK models to affect short-run inflation dynamics and that the long-run is simply the sum of all "short runs", Thornton (2014) concludes that there is no role for money in this model even in the long-run. Thus, an essential question arises: How can NK models be modified to yield a non-trivial role for money?

\subsection{Money's Role for Monetary Policy Transmission and its Consequences for the Long- Term Link to Inflation}

One central assumption in NK theory is that steadystate inflation always equals the monetary authority's credible inflation target. The consequence of this assumption is simple: Any change in the long-term average of inflation is interpreted as a result of a change in the central bank's desired inflation rate (e.g. Galí, 2002). In addition, the standard NK view implies that the central bank can steer interest rates without considering money demand and supply. Movements in real money balances are driven either by current output - which is (indirectly) determined by the IS relation - or the current short-term interest rate - set by the central bank - if they are not anyway considered as pure noise, i.e. as a money demand shock $\varepsilon^{m}$. Many researchers in NK modelling spent effort on challenging the view that money does not affect inflation, even in the long-run (see, e.g., Nelson, 2008; Ireland, 2004b). ${ }^{21}$ Nelson (2008) is most explicit about this point. He argues that in monetary economics, the term long-run is generally defined as the conditions prevailing after all prices have fully adjusted to monetary policy actions. This illustrates that price stickiness is a temporary phenomenon only. ${ }^{22}$ Moreover, monetary policy is not able to control the real interest rate permanently. This indeed raises the question how the central bank can

\footnotetext{
${ }^{21}$ The simulations within a standard NK model in McCallum \& Nelson (2011, ch. 6.2) suggest that the leading indicator property of money growth for inflation is even present at the business cycle frequency.

${ }^{22}$ This fact is not denied in NK literature. For example, the well-known concept of Calvo pricing (Calvo, 1983) allows some fraction of the population of firms to adjust prices each period. Since in every single period the firms that adjust are selected randomly, all firms have adjusted their prices after an (theoretically) infinite period of time.
}

determine inflation in the long run, i.e. how it can steer actual inflation to its target rate. As monetary neutrality is assumed to prevail, the relative change of the price level has to be equal to the relative change in the nominal money stock. The latter, in turn, is influenced by the central bank via its monetary policy instruments (e.g. open market operations), even in the long run. Consequently, "reaching the inflation target means a specified quantity of open market operations in the steady state; specifically, open market operations that deliver a steady-state money growth" (Nelson, 2008, 1805).

A prominent role in monetary policy transmission can be assigned to the banking system, which is often disregarded in NK models. However, as soon as one explicitly accounts for financial intermediation in a banking system, a role for money emerges. For instance, Zanetti (2012) shows that augmenting a standard NK model with even a simple banking sector that "produces" deposits households can use to finance consumption results in a significant role of money in the business cycle. This is because money is crucial for households' intertemporal allocation of consumption. Moreover, introducing banks leaves the deep coefficients of the theoretical framework unchanged and thus avoids that the model becomes subject to the Lucas (1976) critique. Despite these theoretical advances, Zanetti admits that the omission of money in his model hardly changes the variables' reaction to shocks, raising doubts against money's significance for the modelled transmission mechanism.

Matsuoka (2011) investigates optimal monetary policy in an overlapping generations setting that comprises a banking sector to provide liquidity. In his model, a transactions role of money emerges due to spatial separation and limited communication among economic agents. His optimality conditions depend essentially on the competitive structure of the banking system. For instance, in a monopolistic banking system the Friedman rule $^{23}$ can eliminate banks' monopoly power - and thus the inefficiencies related to it - that emerges under positive nominal interest rates. As a result, monetary policy should not only pay attention to the development of money, but must also take the institutional environment into consideration. Matsuoka's results thus ultimately suggest that the importance of

\footnotetext{
${ }^{23}$ "Our final rule for the optimum quantity of money is that it will be attained by a rate of price deflation that makes the nominal rate of interest equal to zero." (Friedman, 2006, 34).
} 
money in the conduct of monetary policy might vary among countries, governed by, inter alia, the structure of the banking system.

Goodfriend (2005) also investigates the transmission of monetary policy decisions. His model puts particular emphasis on the role of a broad monetary aggregate (including bank deposits) amid the interaction of supply and demand for (broad) money, loan production, asset markets and possible arbitrage between banking services and asset markets. ${ }^{24}$ Therein, households demand deposits to hedge against liquidity risk (which is caused by the timing structure of income flows and households' consumption decisions). Deposits, in turn, originate from collateralised loans, which are produced by banks due to their (risk) management competency. This gives rise to an external finance premium as part of the interest rate for loans to households. The external finance premium, for its part, is governed by households' volume of borrowing relative to collateral. Via a noarbitrage condition, the interest rate on bank loans (and hence the external finance premium) is linked to the interbank interest rate in particular and the cost of loanable funds in general. The distinguishing feature of Goodfriend's approach is the simultaneous determination of the price of consumption goods and the management effort in banks' loan production. Goodfriend (2005) concludes that the central bank, targeting an interbank interest rate in order to maintain price stability, has to take into account broad liquidity conditions, which are, inter alia, reflected in money.

One obvious question arising from the Goodfriend (2005) model that also touches the implications of the standard NK model is the issue of the central bank's ability to steer interest rates. As mentioned earlier, there can be doubts about the view that a central bank can steer the whole term structure of interest rates at its own and direct discretion. In fact, central banks can expand or limit the volume of liquidity they provide to their counterparts and can - more or less explicitly determine commercial banks' costs of refinancing at the central bank. By doing so, they initiate a complex process of changes in relative (asset) prices and yields.

\footnotetext{
${ }^{24} \mathrm{~A}$ role for a broad monetary aggregate in inflationary processes is also found in Canzoneri et al. (2008) by introducing financial frictions and financial intermediaries in a NK framework. Interestingly, there is no role for a narrow monetary aggregate in this respect. The reason is that the money demand relationship in their model plays an active part in determining households' and banks' demand for various assets and that innovations in broad aggregates contain information about the most important underlying shocks to productivity and government spending.
}

The ultimate effects of the central bank's decision for banks' market-based refinancing costs are, therefore, rather indirect and depend on numerous factors beyond the direct control of the central bank, as experienced in particular during the financial market tensions since $2007 .^{25}$

Another aspect that should be taken into account is central banks' ability to anchor inflation expectations, which are, as highlighted in the policy rule (3), essential in NK models. Christiano et al. (2008) explicitly address this issue. In their view, even if a monetary policy reaction function like (3) might be able to stabilise inflation expectations, it might not do so in any circumstances due to the uncertainty regarding the true data-generating process. If this type of uncertainty occurs, they show that the central bank's credible commitment to monitor and steer non-borrowed reserves (i.e. money supply) is helpful in stabilising inflation expectations in case money evolves not in line with fundamentals (Christiano et al., 2008, 33). Money, in this sense, is used as an escape clause strategy for special circumstances. Such a strategy works if the central bank is able to credibly commit to control money in the case the escape clause is activated. Besides this, the authors look at situations with possible financial market imbalances. They derive that cautious and forward-looking monetary policy which gets restrictive in case of strong credit (money) growth will attenuate boom-bust-cycles in financial markets.

Lastly, Christiano \& Rostagno (2001) review different ways how monetary policy characterized by (3) might increase macroeconomic volatility. They show that a modification to (3) according to which the central bank monitors money growth as well as its commitment to abandon (3) in favour of a money-rule in case money growth left a pre-defined corridor is optimal. A similar reasoning is presented by Minford \& Srinivasan (2010) who argue that NK models should explicitly take money demand and money supply issues into account and formulate a terminal condition for its money supply behaviour. This is necessary to avoid indeterminacy of inflationary processes because the NK argument that agents would not choose a path of hyperinflation due to its disastrous consequences is not credible and does

\footnotetext{
${ }^{25}$ For example, despite the ECB's Governing Council leaving the interest rate on its main refinancing operations unchanged between May 2009 and April 2011 at $1.00 \%$, volatility of the overnight interbank benchmark interest rate EONIA (Euro Overnight Index Average) hiked significantly between July 2010 and September 2011. This documents retrenched control of the interbank interest rate that is considered the starting point of the monetary policy transmission process in the euro area
} 
not rule out such an equilibrium. ${ }^{26}$ Only money provides the central bank with a tool to formulate such a terminal condition and thus an instrument to credibly anchor inflation expectations and rule out bubbles (see also Balfoussia et al, 2011, Brückner \& Schabert, 2006; Cochrane, 2007a, b; Feldkord, 2005)..$^{27}$ Atkeson et al. (2009) show that determinacy can be re-established by employing sophisticated monetary policy rules where the monetary authority switches from an interest rate rule to a money growth rule. ${ }^{28}$

\subsection{Incorporating Money into NK Theory}

As argued above, there are convincing arguments against the view that there is no role for money for economic developments in general and monetary policy in particular. Consequently, researchers tried to incorporate money into theoretical Dynamic Stochastic General Equilibrium (DSGE) models (which are built on the basis of NK theory) ${ }^{29}$ by including money directly into the utility or production function of agents or firms. Therefore, the resulting models are called money-inthe-utility-function (MIU) (see e.g. Woodford, 2003, ch. 2) or money-in-the-production-function models (see e.g. Canova \& Menz, 2011; Benchimol, 2014a). ${ }^{30}$

\footnotetext{
${ }^{26}$ Determinacy is less of a problem if the equilibrium is learnable. However, it is well known that non-activist interest rate rules $\left(\omega_{\pi}<1\right)$ like $(3)$ do not give rise to any learnable rational expectations equilibrium as the Taylor principle is violated (e.g. Woodford, 2003, 261ff.). In this sense, a non-activist money growth rule (i.e. constant money growth rate) is preferable as it guarantees a single non-explosive solution that is learnable (McCallum \& Nelson, 2011, ch. 8.2). In this rational expectation equilibrium inflation equals money growth after taking advances in payments technology and financial innovation into account.

${ }^{27}$ The latter paper also considers a broad monetary aggregate.

${ }^{28}$ Atkeson et al. (2009) define "sophisticated policy rules" to be dependent on past private actions.

${ }^{29}$ Strictly speaking, also Real Business Cycle (RBC) models can be interpreted as DSGE models since they are dynamic, stochastic and are dealing with general equilibriums. The only distinguishing feature between RBC and NK (i.e. DSGE) models is that the latter allow for nominal rigidities, while RBC models usually deal with flexible prices (see, e.g., Goodfriend \& King, 1997).

${ }^{30}$ Holman (1998) postulates that money-in-the utility-function models allow for transactions as well as precautionary and store-of-value motives for holding money. Another common strand of the literature is the so-called cash-inadvance (CIA) approach. Its fundamental idea is that financing certain types of transactions necessitates holding money balances. Bhattacharjee \& Thoenissen (2007) compare the CIA and the MIU methods of motivating money in New Keynesian DSGE models together with alternative monetary policy feedback rules. They find that the CIA model closed by a money growth rule comes closest to the data. However, Feenstra (1986) has shown that the CIA model is a special case of the MIU approach. In addition, Wallace (2011) criticizes that the CIA approach, or generally models with asset-specific transaction-costs, do not allow to analyse alternative ways of achieving specific distributions of assets among agents in the economy. Therefore, in what follows, we concentrate on MIU models. The MIU approach found further motivations in the context of shopping time models (see e.g. Bakhshi et al., 2002), which state that money holdings allow economic agents to reduce shopping and transactions time. Croushore (1993) shows that MIU and shopping time models are functionally equivalent. McCallum (2000) presents a reduced form shorthand of all these analyses by introducing a transactions cost function which reflects the transaction-facilitating properties of money, in the per-period budget constraint. Another approach to rationalize money's role as a medium of exchange (and store of value) in a world with trading frictions would be overlapping generations models (Champ et al., 2011).
}

The ultimate conviction of MIU models is that holding money itself yields direct or indirect utility. Consequently, money appears in the household's utility function $u($.$) . In the basic theoretical set-up, households$ are assumed to be infinitely-lived and aim at maximising their expected lifetime-utility of the form

$$
E_{0}\left[\sum_{t=0}^{\infty} \beta^{t} u\left(c_{t}, m_{t}\right)\right],
$$

where $0<\beta<1$ is the discount factor, $E$ is the expectation operator and the per-period utility depends positively on consumption $c$ and real balances $m=$ $M / P$. The way money affects the consumption path crucially depends on the assumption made about $u_{c m}$, i.e. what happens to the marginal utility of consumption if real money balances change.

If $u($.$) is additively separable between c$ and $m$, the marginal utility of consumption would be independent of real balances. There would be no real balance effect beyond the fact that money enters the utility function. In contrast, if $u($.$) is assumed to be non-separable across$ its arguments, there indeed arises a role for money since real balances enter the model's IS and Phillips curve, as shown in Woodford (2003), Ireland (2004) and Andrés et al. (2006), among others. Andrés et al. (2009), Canova \& Menz (2011) and Castelnuovo (2012) bring these models to the data. Andrés et al. (2009) find evidence for the forward-looking character of money demand and for its value in identifying variations in the natural rate of interest and the realinterest rate gap. In addition, Castelnuovo (2012) estimates a structural DSGE monetary model of the business cycle for the US economy in which money is allowed, but not necessarily required, to play a role. In his model, money may exert an influence via nonseparability, direct (via portfolio adjustment costs) effects and / or the impact of policy-maker's systematic reaction to monetary developments. Castelnuovo finds that money, as measured via M2, plays a significant role in shaping the US business cycle, even though its significance is time-varying. ${ }^{31}$ The effects are first and foremost stemming from non-separability and from policy-makers' systematic reaction to monetary developments. At the same time, these results are not true for the monetary base.

\footnotetext{
${ }^{31}$ Canova \& Menz (2011) also provide evidence on the time-varying character of the impact of money on economic developments.
} 
Benchimol \& Fourçans (2012) also provide a model based on non-separable utility to particularly investigate the link between risk-aversion and money demand highlighted already in Friedman (1956). Accordingly, agents' money demand should pick-up with risk-aversion in order to cope with uncertainty and to optimise the intertemporal allocation of consumption. Indeed, Benchimol \& Fourçans (2012) find evidence for money's role in determining output (fluctuations) for high-levels of risk-aversion (for an application to the euro area see Benchimol, 2014b). Consequently, riskaversion potentially affects money's impact on relative prices in goods as well as financial markets with repercussions on aggregate demand and output. ${ }^{32}$ In addition, Benchimol \& Fourçans (2012) argue that the role of money for macroeconomic dynamics is usually masked in standard NK models' endogenous inertia regarding output (via consumption habits) and inflation (via price indexation). In fact, output and inflation seem to be more forward looking than implied by these inertial components, providing another conduit for money to affect economic outcomes.

Apart from the discussion about (non-)separability of utility, Woodford's $(1998,2003$ ch. 2.3.4) case of a "cashless limiting economy" does also controvert the impact of money on economic developments. In his model, agents need money to finance transactions, but the volume of money that is actually used for transactions tends to zero due to innovations in financial markets and payment systems. Consequently, the velocity of money approaches infinity, resulting in households' holdings of real balances falling to zero. The marginal utility of additional real balances becomes large in such an environment. Thus, it is possible to arrive at an equilibrium exhibiting a nontrivial interest-rate differential between monetary and non-monetary assets and significant opportunity costs of holding money. At the same time, variations in the stock of money hardly have any effects on the marginal utility of consumption as money becomes increasingly unimportant for transactions, resulting in an equilibrium with real balances being very small relative to national income. The underlying idea of this view is that in such an economy money is used for transactions of only a very few kinds, though it is essential for those.

The assessment whether or not the assumptions of separability of the utility-function or that of a cashless-

\footnotetext{
${ }^{32}$ Another way to introduce money in DSGE models would be to substitute the monetary policy reaction function (3) with a money rule. Christiano et al. (2003) show that if such a rule had been in place, the Great Depression would have been relatively mild.
}

limit environment are relevant and quantitatively important is ultimately an empirical question. However, even on theoretical grounds, both of these assumptions seem questionable. For instance, cash certainly provides valuable services to consumers which may stem from its anonymity or from the fact that transactions can be conducted via money without knowledge of individual histories (imperfect monitoring), imperfect recognisability or costly connections among people (Wallace, 2011). ${ }^{33}$ Against this background, McCallum $(2000,2001,2002)$ strongly argues that there is no compelling theoretical basis for the assumption of separability of the utility function. Moreover, as Ireland (2004b) states, introducing real balances into a forward-looking IS curve necessarily requires introducing real balances into a forwardlooking Phillips curve. By doing so, Barthélemy et al. (2008) achieve a direct effect of money on output and inflation and find a non-trivial role for money in the business cycle.

\subsection{The Information Channel of Money}

A number of NK models, summarised by the term information channel literature, (see Beck \& Wieland, 2007, 2008; Coenen et al., 2005) assign money a prominent role for monetary policy due to its leading indicator property for the underlying state of the economy. Within this strand of literature, one can further distinguish between models arguing via money's informational content regarding (potential) output or the natural rate of interest, while other models focus on the information money provides for asset price developments.

\subsubsection{Money as an Indicator to Improve Perceptions of Output and Interest Rates}

As regards money's informational content with respect to the mitigation of problems arising from misperceptions of either the level of output or the real interest rate, Coenen et al. (2005) refer to money's leading indicator property amid data revisions. According to their results, money can improve the precision of output estimates since aggregate money demand is governed by the true level of aggregate demand whereas the central bank can observe only a noisy measure of aggregate output. However, a useful indicator property of money necessitates (i) a lower variance of money demand shocks compared to that of

\footnotetext{
${ }^{33}$ See part 4 below for a detailed discussion of the related New Monetarist view to money's role in the economy.
} 
output mismeasurements and (ii) a relatively close contemporaneous link between money and aggregate demand. Coenen et al. (2005) have to admit that the latter of these two pre-requisites seems to be hardly fulfilled in the euro area.

The role of money in dealing with data uncertainty is also highlighted in Scharnagl et al. (2010) in an extension of the analysis of simple monetary policy rules to the case where policy-makers face measurement problems with respect to both actual and potential output. They change the standard NK model (1) - (3) by including a money demand function (which depends on actual output) and degrees of output gap uncertainty found in practice. With these simple modifications they find that a speed-limit rule which includes an additional response to money growth outperforms both the standard speed-limit rule and more conventional Taylor rules (with and without money). ${ }^{34}$ The main reasons for the welfare gain are that money growth contains information on current output growth and that data on the euro area money stock are subject to only negligible measurement errors. ${ }^{35}$ Beck \& Wieland $(2007,2008)$, too, allow for persistent central bank misperceptions regarding potential output. They show that under this assumption, cross-checking the optimal (discretionary) policy response derived from NK models with money-based estimates of trend inflation generates substantial stabilisation benefits (see also Arestis et al., 2010). These results might be subject to criticism regarding the assumption of the persistence of the central bank's misperception of potential output, in particular against the backdrop of academic advances in nowcasting macro-economic variables (see Evans, 2005, among others). However, Beck \& Wieland actually base their assumption on a couple of studies supporting their view of relatively long-lasting misperceptions (see, e.g., Orphanides, 2003; Gerberding et al., 2005).

\subsubsection{Money as an Instrument to Improve the Understanding of Asset Price Fluctuations}

A second strand within the information channel literature refers to money being a good proxy for a

\footnotetext{
${ }^{34}$ In their approach, performance of different interest rate rules is measured by a commonly used central bank loss function which aims at minimising the variances of inflation around its target, of the output gap and interest rate changes, respectively (e.g. Rudebusch \& Svensson, 1999; Ehrmann \& Smets, 2003; Coenen et al., 2005).

${ }^{35}$ As a side benefit, monetary policy responding to monetary developments automatically introduces inertia and history-dependence into the policy rule (Gerberding et al., 2009; Söderström, 2005), both of which are robustness characteristics of forward-looking models to stabilise inflation expectations, as demonstrated in Woodford (2003, ch. 8).
}

whole set of asset price developments which are not well captured by short-term interest rates alone. Therefore, NK models tend to understate the value of money as an indicator for monetary policy due to recognising an insufficient number of distinct assets by presuming perfect substitutability between nonmonetary assets. Nelson (2002, 2003) presents an alternative theoretical framework. Therein, money is important to aggregate demand because of its leading indicator property for various substitution effects among assets- which, in turn, matter for aggregate demand triggered by monetary policy decisions which changes asset prices and yields.

Kajanoja's (2003) model supports the benefits of this leading indicator property of money, in particular when money-demand is forward-looking, because it enables policy-makers to learn faster about the various shocks the economy is exposed to. ${ }^{36}$ This is because the growth rate of real balances, being affected by the nominal interest rate steered by the monetary authority, contains information about the real interest rate and the economy's potential output. The distinguishing feature of this approach is the forward-looking money demand function, since in a static money demand framework all information about the natural rate of output is already contained in current output and the nominal interest rate.

The forward-looking character of money demand is empirically confirmed by Andrés et al. (2009) for MIU models with non-separable utility and for CIA models. Thus, there is evidence that real money balances are valuable for anticipating future variations in the natural real interest rate, which are otherwise difficult to gauge. The reasoning is that real balances reflect agents' portfolio adjustments in response to aggregate demand and / or technology shocks to which they are exposed to. ${ }^{37}$ Ullersma et al. (2006) also augment a standard NK model with the idea of money being a proxy for the yields of different assets which matter for aggregate demand, but cannot be incorporated into the model. Welfare gains are achieved if the monetary authority takes money growth explicitly into account when setting interest rates, because doing so allows an assessment of the resulting developments in asset prices that are relevant for aggregate demand and thus for inflation. Furthermore, since money reveals information on

\footnotetext{
${ }^{36}$ Output shocks, inflation shocks and interest rate shocks are considered. He derives the forward-looking money demand function within a model based on portfolio adjustment costs for real balances.

${ }^{37}$ Further empirical support for this outcome is provided in Nelson (2002)
} 
determinants of aggregate demand beyond the shortterm interest rate, it leads to a better estimation of the natural real interest rate. Hence, considering money enables the central bank to improve its understanding of the transmission process of monetary policy.

In a similar vein, McCallum \& Nelson $(2011,144)$ present historical evidence for the general idea that money reveals fluctuations in variables, which are hard to be observed directly, but nevertheless matter for future aggregate demand - in particular the natural rate of interest. Moreover, an assessment of the monetary policy stance is more reliable when it takes monetary aggregates into account instead of focusing solely on interest rates. For instance, Tödter (2002) shows that money can be interpreted as being a "summary statistic" of different shocks hitting the economy (the $\varepsilon^{i}$ terms in (1) - (4)), even though money does not allow to identify the respective individual shocks $\dot{\varepsilon}$.

\section{NEW MONETARIST ECONOMICS}

In recent years, a new school of thought has established, New Monetarist Economics. ${ }^{38}$ What is their thinking about the role and concept of money? And what's so new with the New Monetarists (NM)? In fact, both "Old" and "New" Monetarist models stress the importance of money and concentrate on welfare aspects that makes them being focused on rather longrun issues. Apart from that, the two approaches have hardly anything in common. ${ }^{39}$ For example, the conclusions of the NM literature are grounded in formal and microeconomic theory, while the traditional approach was based on rather ad-hoc assumptions. From an institutional design perspective, one of the most important distinguishing features of NM models is that they explicitly take the role of financial intermediaries and their interactions with the central bank into account. ${ }^{40}$

Like NK models, the NM literature also highlights the importance of economic frictions. However, the

\footnotetext{
${ }^{38}$ The term "New Monetarist Economics" is introduced in Williamson \& Wright (2011). It has close connections to the "mechanism-design approach to monetary theory", as used in Wallace (2011). A textbook treatment of different aspects of NM ideas can be found in Nosal \& Rocheteau (2011).

${ }^{39} \mathrm{An}$ introduction to New Monetarist models, including a comparison between the "Old" and "New" Monetarist literature is provided in Williamson \& Wright (2011, p. 271 ff.). For recent overviews of NM models see Williamson \& Wright (2010, 2011)

${ }^{40}$ As a consequence, NM models realise that banks perform a socially beneficial function in transforming illiquid assets into liquid liabilities and helping to reduce asymmetric information problems and transaction costs. Thus, they frequently conclude that reserve requirements of $100 \%$, as previously urged by Old Monetarists, inefficiently preclude this activity. Furthermore, as New Monetarist models explicitly account for the exchange process, they are especially suited to study payments and settlement systems like TARGET2 or Fedwire.
}

differences are in the details. For example, frictions in NM theory are modelled explicitly and are not based on assumptions as is common in NK models. Additionally, the kinds of restrictions for the optimisation process are different. Imperfect monitoring together with limited commitment and asymmetric information about both a counterpart's credit standing and the traded good's features and quality are in the NM approach's centre of interest. This has far-reaching consequences as money now actually is the key to ameliorate frictions. Consequently, the NM approach is able to show that spatial separation per se is not the critical friction making money essential. ${ }^{41}$

The fundamental idea behind that view is that money helps to resolve the double-coincidence-ofwants problem in an environment subject to the abovementioned restrictions to the optimisation process. ${ }^{42}$ As regards imperfect monitoring amid limited commitment this is because money can serve as a kind of memory (Kocherlakota, 1998). ${ }^{43}$ In other words, money can be used as evidence of an agent's actions in the past, weakening his incentives to cheat (Wallace, 2011). Thus, imperfect monitoring implies incomplete recordkeeping that ultimately gives rise to asymmetric information about the history of transactions. ${ }^{44}$ To put it differently, imperfect monitoring results in uncertainty regarding an agent's credit standing. In the extreme case of no monitoring at all, all transactions should thus be conducted via money. Thus, money comes into play via incomplete memory, which is traditionally formalised by assuming anonymous agents in NM models. At the same time, conditions for credit are best in an environment in which there is full monitoring. Consequently, if one aims at modelling money and credit simultaneously, it is necessary to limit monitoring sufficiently to make a case for money, while leaving its level adequately high to enable credit.

\footnotetext{
${ }^{41}$ Matsuoka (2011) concludes that a transactions role for money emerges due to spatial separation and limited communication in an overlapping generations model.

${ }^{42}$ Double coincidence is the situation where the supplier of good $x$ wants good $z$ and the supplier of good $z$ wants good $x$. Accordingly, single coincidence means that either of the two conditions is not met. The double-coincidence-ofwants problem arises whenever two agents meet for a transaction and only one of them can offer an asset or good his counterparty is interested in. In this circumstance (so-called "single-coincidence meeting", Williamson \& Wright, 2011), direct barter is not possible, so trading against a medium-of-exchange, that is usually interpreted to be "money", can facilitate trade.

${ }^{43}$ In this context, limited or no commitment means agents' lack of agreement on a particular allocation of resources (Kocherlakota, 1998). If there are severa potential suppliers of money, an efficient solution can once again only be guaranteed by the existence of trust, not by competition alone. Therefore, Marimon et al. (2012) call money an experience good.

${ }^{44}$ Asymmetric information is also an issue when it comes to the features and quality of the goods to be traded. This issue is frequently discussed under the term "imperfect recognisability" (Wallace, 2011).
} 
From a methodological point of view, NM models have in common a search-based structure (see for one of the first papers Kiyotaki \& Wright, 1993). Though varying in their theoretical details, a general conclusion is that a shortage of a medium of exchange is costly because trades do not occur that actually would be welfare-improving (Williamson \& Wright, 2011). For illustrative purposes, imagine a very simple economy with a worthless object which may be stored in units $m$ $\in\{0,1\}{ }^{45}$ For the sake of simplicity, let us call this object "money", even though doing so is not fully in line with the usual definition of money employed in central banks. Next, assume that whenever two agents meet, each of them is endowed with "money" (i.e. $m=1$ ) with probability $p$. Consequently, the probability of someone not having money at his disposal (i.e. $m=0$ ) is $1-p$. If we define $V_{m}$ to be the payoff of an agent with "money", the payoff $V_{0}$ ( $m=0$, i.e. not having money) is given by

$V_{0}=\beta V_{0}+\alpha \delta(U-C)+\alpha \sigma p \max _{\phi} \phi\left[-C+\beta\left(V_{1}-V_{0}\right)\right]$,

where $B$ is a discount factor, $U$ is utility obtained from consuming a good produced by someone else and $C$ represents the cost of producing goods. ${ }^{46}$ The parameter $\alpha$ describes the probability that two agents meet while $\delta$ is the probability that both of them like what their counterpart produces (so-called "doublecoincidence meeting"). Double-coincidence meetings increase the payoff in the case without money (depending on the two probabilities) as utility $U$ exceeds the costs of the good $C$. By contrast, $\sigma$ is the probability that only one of the two agents is willing to transact, whereas the other is not (so-called "singlecoincidence meeting"). In this case, $\phi$ is the probability that the one not endowed with "money" actually agrees to sell his good for "money". Single coincidence additionally improves the situation (depending on the probabilities) as the producer costs $C$ are lower than the payoff increase meeting someone having money (see the third term in (6)). In double coincidence meetings (the second term in (6)), the agent can still barter, but with money he has one further option. If he meets a person with money who likes his good, he can trade for cash and $\phi$ is the probability he agrees to do so.

In case the agent is endowed with money, the payoff $V_{1}(m=1)$ is given by

\footnotetext{
${ }^{45}$ If $m$ is used as a medium of exchange, it is by definition fiat money (Wallace, 1980).

${ }^{46} \mathrm{C}$ may alternatively be interpreted as the opportunity cost of forgoing one good with utility $C$ in exchange for another good with utility $U$.
}

$V_{1}=\beta V_{1}+\alpha \delta(U-C)+\alpha \sigma(1-p) \varphi\left[U+\beta\left(V_{0}-V_{1}\right)\right]$,

where $\varphi$ is the probability that the agent's money offered in a single-coincidence meetings is accepted. Again, he can still barter in double-coincidence meetings. However, in the single-coincidence case (the last term in (7)) having money is useful for him as he can make a cash offer to get the good, which is accepted with probability $\varphi$.

Equations (6) and (7) show that as long as a double-coincidence meeting takes place, agents have always the option to barter. In this case, there is no role for money left. However, as soon as one of the two agents is not interested in the good his counterpart owns, money provides the opportunity to trade for money (as captured by the third term in the respective equations). As a result, money enables transactions in single-coincidence meetings, which would not have occurred without money.

More formally, in a system like the one described, an equilibrium is defined as a set $\left\{\phi, V_{0}, V_{1}\right\}$ which satisfies (6) and (7) combined with a so-called best response condition (i.e. maximised value of $\phi$ given $\varphi$ ). There is a monetary equilibrium $\phi=1$, if and only if $C$ is not too high. ${ }^{47}$ This equilibrium is superior to barter and is robust. However, it can be shown that it does not as well as perfect credit (Williamson \& Wright, 2011, 34). Thus, money is not a perfect substitute for credit. ${ }^{48}$ Nevertheless, the intrinsically worthless asset $m$ has a positive value in monetary equilibriums as a medium of exchange or due to its liquidity. The money demand function inherent in these models is well-defined and fairly standard. It specifies real balances proportional to income and the proportionality factor to depend negatively on the interest rate (Williamson \& Wright, 2011, 46).

As an interim result, we notice that NM theory provides a rationale for both the existence of money and credit - a fundamental advance in rationalising the potential usefulness of money for monetary policy purposes. However, from a monetary policy perspective, some questions yet remain: What are the costs of inflation implied in NM models? What assets do actually exhibit the features of "money"? And should

\footnotetext{
${ }^{47}$ In contrast, $\phi=0$ is also a possible equilibrium outcome which directs attention to possible instabilities of fiat money systems.

${ }^{48}$ Gomis-Porqueras \& Sanches (2013) even show that fiat money complements the use of credit in transactions if access to credit is restricted.
} 
monetary policy makers care about money when they aim at maintaining price stability?

Some intuitive answers to these questions can be directly obtained from (6) and (7). For example, whenever high (anticipated) inflation rates result in a loss of money's medium-of-exchange feature, welfare (measured via the value function $V_{m}$ ) in the NM model will decline as the parameter $\phi$ shrinks. In addition, inflation is likely to increase the cost of producing goods $(C)$, which also decreases $V_{m}$.

In order to address these questions in more detail, it seems reasonable to extend this NM model to directly account for inflation. The simple environment used above is not capable of doing so since prices are fixed. This assumption is relaxed, for example, in Williamson \& Wright (2010) who refer to models introduced by Shi (1995) and Trejos \& Wright (1995). Williamson \& Wright (2010) show that in this environment the price level increases with the number of consumers. Leaving distributional considerations aside, this implies that the price level co-varies positively with money. Policy makers can either target money growth, the inflation rate or the nominal interest rate which all are equivalent in this model. At the same time, in the stochastic version of the model, many paths of monetary developments can be consistent with a specific level of interest rates. Lastly, NM models find that the costs of (both anticipated and unanticipated) inflation, which in NM models are due to intertemporal distortions, are much higher than in NK models.

New Monetarists find substantial flaws in New Keynesian ideas (Williamson \& Wright, 2010, 269ff.). Their main point of critique is the weak foundation of the assumption of nominal rigidities, in particular price stickiness, in the sense that prices cannot be changed except at times specified rather arbitrarily (e.g. Calvo pricing) or at some menu cost. In these kinds of settings, money does not help resolving the problems, but is often, e.g. in CIA models, the cause of them. In contrast, New Monetarists are convinced that price stickiness should be the endogenous result of a model, not exogenously postulated. In their view, price stickiness is, if at all, a friction of the mechanism (design) and not in the environment (like private information, lack of commitment, imperfect recognisability or incomplete record keeping). They concentrate on the frictions in the environment as price stickiness (or sticky information) by assumption excludes some gains from trade. New Monetarists hence explicitly describe the frictions in the exchange process.
To substantiate the NM convictions, Williamson \& Wright (2011, ch. 4) impose price stickiness like in NK models to show that confining monetary policy to the cashless limit case as done in Woodford (2003) is dangerous. The key difference between a model with money and credit and the cashless economy is that in the former the behaviour of prices is tied to the behaviour of the aggregate money stock, in line with the quantity theory of money. Only the model with money provides control over a monetary quantity to the monetary authority. The most important theoretical message of this kind of exercise is that if one thinks it is critical to have nominal rigidities in a model, this is not inconsistent with theories that try to be explicit about the exchange process and the role of money or related institutions in that process. Alternatively, Williamson \& Wright (2011) use a search model to get nominal rigidities to emerge endogenously. It's main contribution to the theoretical discussion is that this model delivers monetary neutrality - a characteristic not existent in NK models - and reveals that sticky prices per se do not logically constitute evidence of the non-neutrality of money. ${ }^{49}$

Turning to the empirical evidence on NM models, there are only few empirical studies available as yet. Those existing usually focus on money's unique medium-of-exchange function, the natural empirical counterpart of which is a narrow or transactions-related definition of money, like M0 (in particular currency in circulation) or M1. Therefore, M1's good leading indicator properties for GDP growth may find some intuition in NM models (see for the euro area Brand et al., 2004). Alternatively, monetary services index numbers could be in the spirit of NM models, since they are derived from first principles. However, not all of the components included in these liquidity-weighted aggregates may be directly used in transactions. Consequently, NM models usually distinguish between currency in circulation and bank liabilities, respectively. However, referring to Lucas (2000), Williamson \& Wright $(2010$, p. 281$)$ note that a too narrow measure of money would take the theory probably too literally. Since in principle almost any asset can exhibit

\footnotetext{
${ }^{49}$ Aruoba \& Schorfheide (2011) develop a DSGE model (see section 2) with a centralised and decentralised market. Activities in the centralised market resemble those in a standard NK economy with price rigidities. The presence of a decentralised market creates an incentive for households to hold money and money's role as a medium of exchange emerges endogenously. They show that the long-run distortions from monetary frictions may be of similar magnitude as the distortions created by the New Keynesian frictions.
} 
transaction-related features in NM models, ${ }^{50}$ more empirical research is needed to find the best measure for money. The models itself do not favour one aggregation scheme above another, e.g. simple-sum vs. weighted monetary aggregates.

\section{FINANCIAL INTERMEDIATION}

As stated earlier, New Monetarist models explicitly take financial intermediation into account. However, this is usually not done by explicitly modelling a banking sector. In the NK literature, there are models with an accentuated banking industry, though these approaches do so in order to investigate the granting of credit rather than analysing the emergence of a special role of money. In a world where risk is important (i.e. certainty equivalence does not hold), where money is broadly defined and where money supply is not perfectly elastic, the banking sector actually plays an active role in the transmission process. The frictions money helps to overcome in financial markets are related to its role in providing liquidity services which, in turn, improve the understanding of the evolution of asset prices (King, 2002). This is where financial intermediaries as suppliers of (inside) money come into play. As a consequence, as long as theoretical models do not account for a banking system to explicitly consider both credit and money, they will hardly be able to assign a non-trivial role to money.

Indeed, Zanetti (2012) shows that augmenting a standard NK model even with a simple banking sector in order to introduce deposits that households can use to finance consumption results in a significant role of money in the business cycle (see section 3 above). Moreover, financial intermediation becomes relevant for monetary policy purposes via the link between price stability and financial stability. This is because financial intermediaries are key players in the monetary transmission process: they create inside money (issue demand deposits) and may stabilise or destabilise

\footnotetext{
${ }^{50}$ "Note as well that theory provides no particular rationale for adding up certain public and private liabilities (in this case currency and bank deposits), calling the sum money, and attaching some special significance to it. Indeed, there are equilibria in the model where currency and bank deposits are both used in some of the same transactions, both bear the same rate of return, and the stocks of both turn over once each period. (...) But what the model tells us is that public and private liquidity play quite different roles. (...) We see no real purpose in drawing some boundary between one set of assets and another, and calling members of one set money." (Williamson \& Wright, 2010, 294). Consequently, the NM view is not necessarily in contrast to the NK conviction that a central bank does not need to monitor monetary developments as agents' habits to transact can change that quickly that whatever definition of a monetary aggregate will not be able to explain inflationary processes (Woodford, 1998)
}

financial markets via their daily business. This link is well-elaborated in Brunnermeier \& Sannikov (2011), introducing a modern approach called the "I Theory of Money" which combines intermediation and inside money. It highlights the role of money as a store of value, liquidity buffer or insurance device instead of its transactions feature. In contrast to NK models, prices are fully flexible in their setup and households are assumed to be heterogenous. In such an environment, financial intermediaries can mitigate or even overcome financial frictions like asymmetric information. However, the intermediation process involves risks which give rise to two possible equilibrium outcomes (see also Brunnermeier et al., 2011). In the first equilibrium, the financial sector is well capitalised and banks create a large quantity of inside money by lending freely. Outside money is not really needed and hence has low value as agents have alternative ways to undertake transactions and hold money for precautionary reasons. They can hold deposits with intermediaries or purchase securities from non-financial corporations. Banks are mainly funded by deposits that emerge from intermediaries' lending activity. However, a negative aggregate shock can shrink financial institutions' net assets and is hence capable of impairing their intermediation activity and the creation of inside money. This leads to the second equilibrium. Due to growing risk and uncertainty, precautionary money demand increases, leading to an increasing value of outside money. This, in turn, leads to a collapse of the (endogenous) money multiplier and thus ultimately to deflation (as in the early monetarist literature). Monetary policy can mitigate these adverse effects by redistributing money towards the financial sector (expost). ${ }^{51}$

In this sense, money, liquidity and financial frictions are inter-related. With financial frictions, a temporary adverse shock may be highly persistent, possibly generates amplification effects through intermediaries' balance sheets (e.g. negative liquidity spirals) and may lead to instability of financial markets. In anticipation of potential adverse shocks, the demand for liquid assets (i.e. money) of market participants for precautionary reasons will rise. This holds particularly true for monetary and non-monetary financial intermediaries, but also for non-banks. The higher the degree of liquidity or "moneyness" of assets, the better this liquidity buffer is. The essential distinction within the I-

\footnotetext{
${ }^{51}$ However, by reducing losses that financial intermediaries are exposed to, such a policy creates moral hazard problems ex-ante.
} 
Theory is between inside and outside money which are only imperfect substitutes for each other. ${ }^{52}$

Besides the direct link between money and price stability highlighted in the (old and new) monetarist literature, the I-Theory of Money illustrates the significance of monetary developments for price stability also via a financial stability channel. Alternative approaches frequently highlight the importance of money and financial intermediation for macroprudential issues, but do not take another step forward to relate it to price stability.

For example, Adrian \& Shin (2011) present a New Keynesian DSGE model in which they highlight financial intermediaries' role in determining the price of risk. As these expand their balance sheets, their riskbearing capacity increases and risk premiums fall. Thus, balance sheet quantities (e.g. money on the liability side) are indicators of the risk taking capacity of the whole financial intermediaries sector, the profitability of their projects (e.g. credit) as well as real activity. The broader the concept of money, the better this indicator property is. However, there are important differences between the various financial intermediaries and their respective balance sheet quantities. First, the information provided by institutions that are marking-to-market their balance sheet items is of superior quality. Second, the more market-based a financial system is, the more marketable instruments are useful with regard to this risk taking channel.

In a similar vein, Shin \& Shin (2011) and Hahm et al. (2013) examine to what extent monetary aggregates can serve as an indicator of the stage of the financial cycle (for macroprudential reasons), which is reflected in the composition of the liabilities of the banking sector. However, the traditional classification of money according to the "moneyness" (or ease of settlement) of its components is not very helpful in this respect. The more relevant distinction, according to this theory, is that between core and non-core liabilities of the banking system. The core liabilities of a financial institution are its liabilities to non-MFI domestic creditors (mostly in the form of deposits to households). Consequently, the non-core liabilities consist either of liabilities to another financial institution or of liabilities against a foreign creditor. ${ }^{53}$ In a boom with high credit

\footnotetext{
${ }^{52}$ Indeed, the proponents of this theory hold the view that it is difficult to measure money in the form of M1, M2 or M3 in a meaningful way.

${ }^{53}$ In this respect, the approach is somewhat grounded in deliberations similar to those of the Basel III regulatory framework that considers a stable funding ratio.
}

growth, retail deposits (core liabilities) are usually not sufficient to fund the increase in bank credit. Therefore, other sources of funding must be attracted to fund the expansion in lending. Consequently, either transaction volumes in interbank lending markets increase or financial intermediaries' foreign liabilities extend. In this way, there are close links between procyclicality, systemic risk and the amount of non-core liabilities of financial intermediaries. Usually, non-core liabilities have shorter maturity than other liabilities and lengthen the intermediation chains. ${ }^{54}$

In this context, it seems appropriate to raise the question on banks' input factors and their respective actual output. Usually, theory regards deposits as input factors and credit as their output (see for recent examples Shin \& Shin, 2011; Adrian \& Shin, 2011). In fact, this view highlights banks' term transformation, but it neglects its risk management function. However, the view that banks are using (more or less) risky credit as an input factor to produce - by adding their risk management techniques - riskless deposit opportunities seems to be more appropriate today. At the bottom-line, this view explains the co-existence of banks and exchanges, as exchanges do also provide term transformation when assets are fungible, while they cannot provide these risk management services. This is important because banks, compared to financial markets, have an informational advantage when it comes to granting credit to a debtor due to their close monitoring and experiences they made during longlasting business-relationships. This holds particularly true for the many small savings and cooperative banks with area-wide presence, regional identity and local rootedness. Banks are hence able to reduce information asymmetries between debtors and creditors. The view that credit and (broad) money are the same as "money is the balance sheet counterpart to bank lending" (Kim et al., 2012, 1) thus cannot hold under any circumstances. Modelling money in our understanding thus necessitates introducing information asymmetries in order to account for a realistic role of the banking sector and thus to find a role for money.

A shortcoming of models dealing with macroprudential issues is that they are by construction concerned with downside-risks to price stability rather than with a balanced assessment of the risk of

\footnotetext{
${ }^{54}$ The concrete definition of non-core liabilities used for practical purposes depends on the financial structure of the economy.
} 
deviating from the preferred inflation rate in any direction. For instance, financial stability concerns regarding too little provision of liquidity are that it can cause a credit crunch to the real economy, triggering a recession that might ultimately result in deflation. Alternatively, too much provision of liquidity, from a financial stability perspective, might bear the risk of an asset price bubble, the burst of which can have analogous consequences via the necessary balance sheet adjustments of financial intermediaries in general and the banking industry in particular. Thus, in these theories, the analysis of monetary developments provides useful information from a financial stability point of view, but its applicability for monetary policy purposes is by far broader.

\section{CONCLUSIONS}

Regarding the question of what standard modern macro models regard as "money" it seems that the distinct feature of money is that it is used as a medium of exchange and is (usually) non-interest bearing. This view differs quite significantly from the definition of money that is commonly used in monetary policy practice at central banks. There, money is often defined as containing also interest-bearing short-term assets. This discrepancy in the definition of money in theory and practice poses the empirical question which monetary components actually represent money and contain valuable information for monetary policy to safeguard price stability and financial stability. Of course, the most valuable definition of money must not necessarily coincide with that of M1, M2 or M3 - even more so as these definitions vary among different currency areas. Thus, there is a need for a periodical review of the definition of money against the backdrop of both latest theoretical advances and practical necessities. As regards the former, theory has been by now increasingly successful in finding a non-trivial role for money despite the criticism of the standard New Keynesian framework, although many theories still mainly emphasise money's role as a medium-ofexchange. Regarding the latter, the definition of money must be kept up-to-date in order to account for latest financial innovations which are usually not considered in theoretical models. For example, securitisation activity of MFIs potentially results in monetary statistics on MFIs' granting of loans deviating from their actually relevant origination of loans. A review of the definition of money has thus always to take care of theoretical as well as practical advances.
Anyway, at the bottom line both theory and practical experience guide monetary policy-makers towards one ultimate conclusion: If one accepts price stability as being the primary goal of monetary policy, a discussion of monetary policy without a reference to monetary aggregates seems quite misleading and inconsistent. Inflation is a synonym for a declining value of money, which is determined by supply as well as demand factors. This reasoning can be applied both to the analysis of inflation dynamics and to the determination of steady-state inflation. Against the background of uncertainty, misperceptions and theoretical ambiguities it is advisable to consider money and interest rates in monetary policy analysis and decision-making. In a monetary economy with money as a means of payment, there must be consistency between the target rate of inflation - no matter how it is controlled and which instrument the central bank uses - and the growth rate of money. With an additional financial market stability perspective in mind, this logic can be easily adapted if asset price inflation is included in the measurement of inflation. In a nutshell, money (still) matters!

\section{REFERENCES}

Adalid, Ramón. \& Carsten Detken (2007), Liquidity Shocks and Asset Price Boom/Bust Cycles, ECB Working Paper No. 732, February.

Adrian, Tobias \& Hyun Song Shin (2011), Financial Intermediaries and Monetary Economics, in: B. Friedman and M. Woodford (eds.), Handbook of Monetary Economics, Vol. 3A, NorthHolland, pp. 601-6-650.

Alchian, Armen A. (1977), Why Money? Journal of Money, Credit, and Banking 9, pp. 133-140. http://dx.doi.org/10.2307/1992014

Alessi, Lucia \& Carsten Detken (2011), Quasi Real time Early Warning Indicators for Costly Asset Price Boom/Bust Cycles: a role for global liquidity, European Journal of Political Economy 27, pp. 520-533. http://dx.doi.org/10.1016/i.ejpoleco.2011.01.003

Andrés, Javier, J. David López-Salido \& Javier Vallés (2006), Money in an Estimated Business Cycle Model of the Euro Area, Economic Journal 116, pp. 457-77. http://dx.doi.org/10.1111/j.1468-0297.2006.01088.x

Andrés, Javier, J. David López-Salido \& Edward Nelson (2009), Money and the Natural Rate of Interest: Structural estimates for the United States and the euro area, Journal of Economic Dynamics \& Control 33, pp. 758-776. http://dx.doi.org/10.1016/j.jedc.2008.01.011

Arestis, Philip, Georgios Chortareas \& John D. Tsoukalas (2010), Money and Information in a New Neoclassical Synthesis Framework, The Economic Journal 120, pp. F101-F128. http://dx.doi.org/10.1111/j.1468-0297.2009.02339.x

Aruoba, S. Boragan \& Frank Schorfheide (2011), Sticky Prices Versus Monetary Frictions: An Estimation of Policy Tradeoffs, American Economic Journal: Macroeconomics 3, pp. 60-90.

Atkeson, Andrew, Varadarajan V. Chari \& Patrick J. Kehoe (2009), Sophisticated Monetary Policies, Federal Reserve Bank of Minneapolis Research Department Staff Report 419, May. 
Bakhshi, Hasan, Ben Martin \& Tony Yates (2002), How Uncertain are the Welfare Costs of Inflation? Bank of England Working Paper No. 152, February.

Balfoussia, Hiona, Sophocles N. Brissimis \& Manthos D. Delis (2011), The Theoretical Framework of Monetary Policy Revisited, Bank of Greece Working Paper 138, September.

Barthélemy, Jean, Laurent Clerc \& Magali Marx (2011), A Two-Pillar DSGE Monetary Policy Model for the Euro Area, Economic Modelling 28, pp. 1303-1316. http://dx.doi.org/10.1016/j.econmod.2011.01.010

Beck, Günter \& Volker Wieland (2007), Money in Monetary Policy Design: A formal characterization of ECB-Style crosschecking, Journal of the European Economic Association 5, pp. 524-533.

http://dx.doi.org/10.1162/jeea.2007.5.2-3.524

Beck, Günter \& Volker Wieland (2008), Central Bank Misperceptions and the Role of Money in Interest-rate Rules, Journal of Monetary Economics 55, pp. 1-17. http://dx.doi.org/10.1016/j.jmoneco.2008.07.006

Benchimol, Jonathan (2014a) Money in the Production Function: A New Keynesian DSGE perspective, Southern Economic Journal, In-Press.

Benchimol, Jonathan (2014b), Risk Aversion in the Eurozone, Research in Economics 68, pp. 39-56. http://dx.doi.org/10.1016/j.rie.2013.11.005

Benchimol, Jonathan \& André Fourçans (2012), Money and Risk Aversion in a DSGE Framework: A Bayesian Application to the Euro Zone, Journal of Macroeconomics 34, pp. 95-111. http://dx.doi.org/10.1016/j.jmacro.2011.10.003

Bernanke, Ben S. (2008), Financial Markets, the Economic Outlook, and Monetary Policy, Speech, January 2010.

Bhattacharjee, Arnab \& Christoph Thoenissen (2007), Money and Monetary Policy in Dynamic Stochastic General Equilibrium Models, The Manchester School 75, pp. 88-122. http://dx.doi.org/10.1111/j.1467-9957.2007.01039.x

Borio, Claudio \& Philip Lowe (2002), Asset Prices, Financial and Monetary Stability: Exploring the Nexus, BIS Working Paper No. 114, July.

Brand, Claus, Hans-Eggert Reimers \& Franz Seitz (2004), Narrow Money and the Business Cycle: Theoretical Aspects and Euro Area Evidence, Review of Economics 55, pp. 246-262.

Brückner, Matthias \& Andreas Schabert (2006), Can Money Matter for Interest Rate Policy?, Journal of Economic Dynamics \& Control 30, pp. 2823-2857. http://dx.doi.org/10.1016/j.jedc.2005.09.006

Brunner, Karl (1969), The Drift into Persistent Inflation, Wharton Quarterly (Fall), pp. 23-34.

Brunner, Karl. \& Allan H. Meltzer (1966), A Credit Market Theory of the Money Supply and an Explanation of Two Puzzles in US Monetary Policy, in: T. Bagiotti, (ed.), Investigations in Economic Theory and Methodology, Padova, Cedam.

Brunnermeier, Markus K., Thomas M. Eisenbach \& Yuliy Sannikov (2011), Macroeconomics with Financial Frictions: A Survey, July.

Brunnermeier, Markus K. \& Yuliy Sannikov (2011), The I Theory of Money, June.

Calvo, Guillermo (1983), Staggered Prices in a Utility-Maximizing Framework, Journal of Monetary Economics 12, pp. 383-98. http://dx.doi.org/10.1016/0304-3932(83)90060-0

Calza, Alessandro, Dieter Gerdesmeier, \& Joaquim Levy (2001), Euro Area Money Demand: Measuring the Opportunity Costs Appropriately, IMF Working Paper No. 01/179.

Canova, Fabio \& Tobias Menz (2011), Does Money Matter in Shaping Domestic Business Cycles? An International Investigation, Journal of Money, Credit and Banking 43, pp. 577-607.

http://dx.doi.org/10.1111/j.1538-4616.2011.00388.x
Canova, Fabio \& Filippo Ferroni (2011), Multiple Filtering Devices for the Estimation of Cyclical DSGE Models, Quantitative Economics 2, pp. 73-98. http://dx.doi.org/10.3982/QE36

Canzoneri, Matthew B., Robert Cumby, Behzad Diba \& David LópezSalido (2008), Monetary Aggregates and Liquidity in a NeoWicksellian Framework, National Bank of Belgium Working Paper No. 141, October.

Castelnuovo Efrem (2012), Estimating the Evolution of Money's Role in the U.S. Monetary Business Cycle, Journal of Money, Credit and Banking 44, pp. 23-52. http://dx.doi.org/10.1111/j.1538-4616.2011.00468.x

Champ, Bruce, Scott Freeman \& Joseph Haslag (2011), Modeling Monetary Economies, $3^{\text {rd }}$ ed., Cambridge University Press. http://dx.doi.org/10.1017/CBO9780511977411

Christiano, Lawrence J., Roberto Motto \& Massimo. Rostagno (2003), The Great Depression and the Friedman-Schwartz Hypothesis, Journal of Money, Credit and Banking 35, pp. 1119-1197.

http://dx.doi.org/10.1353/mcb.2004.0023

Christiano, Lawrence J., Roberto Motto \& Massimo Rostagno (2008), Two Reasons why Money and Credit May be useful in Monetary Policy, in: A. Beyer, and L. Reichlin (eds.), The Role of Money - Money and Monetary Policy in the $21^{\text {st }}$ Century, $4^{\text {th }}$ ECB Central Banking Conference, Frankfurt, pp. 28-55.

Christiano, Lawrence J., Roberto Motto \& Massimo Rostagno (2010), Financial Factors in Business Cycle Fluctuations, ECB Working Paper no. 1192.

Christiano, Lawrence J. \& Massimo Rostagno (2001), Money Growth Monitoring and the Taylor Rule, NBER Working Paper no. 8539.

Christiano, Lawrence J., Mathias Trabandt \& Karl Walentin (2011), DSGE Models for Monetary Policy Analysis, in: B. Friedman and M. Woodford (eds.), Handbook of Monetary Economics, Vol. 3A, North-Holland, pp. 285-367.

Clarida, Richard, Jordi Gali \& Mark Gertler (1999), The Science of Monetary Policy: A New Keynesian Perspective, Journal of Economic Literature 37, pp. 1661-1707. http://dx.doi.org/10.1257/jel.37.4.1661

Cochrane, John H. (2007a), Inflation Determination with Taylor Rules: A Critical Review, NBER Working Paper No. 13409.

Cochrane, John H. (2007b), Identification with Taylor Rules: A Critical Review, NBER Working Paper No. 13410.

Cochrane, John H. (2009), Can Learnability Save New-Keynesian Models?, Journal of Monetary Economics 56, pp. 11091113.

http://dx.doi.org/10.1016/i.jmoneco.2009.10.012

Coenen, Günter, Andrew Levin \& Volker Wieland (2005), Data Uncertainty and the Role of Money as an Information Variable for Monetary Policy, European Economic Review 49, pp. $975-1006$.

http://dx.doi.org/10.1016/j.euroecorev.2003.08.005

Croushore, Dean (1993), Money in the Utility Function: A Functional Equivalence to a Shopping-time Model, Journal of Macroeconomics 15, pp. 175-182. http://dx.doi.org/10.1016/0164-0704(93)90060-Y

De Grauwe, Paul \& Magdalena Polan (2005), Is Inflation Always and Everywhere a Monetary Phenomenon? Scandinavian Journal of Economics 107, pp. 239-59. http://dx.doi.org/10.1111/j.1467-9442.2005.00406.x

De Santis, Roberto A., Carlo A. Favero and Barbara Roffia (2013), Euro Area Money Demand and International Portfolio Allocation: A contribution to assessing risks to price stability, Journal of International Money and Finance 32, pp 377-404. http://dx.doi.org/10.1016/j.jimonfin.2012.04.012 
Dreger, Christian \& Jürgen. Wolters (2010), Investigating M3 Money Demand in the Euro Area, Journal of International Money and Finance 29, pp. 111-122. http://dx.doi.org/10.1016/j.jimonfin.2009.02.002

Evans, Martin D. D. (2005), Where Are We Now? Real-Time Estimates of the Macroeconomy, International Journal of Central Banking 1, pp. 127-175.

Feenstra, Robert C. (1986), Functional Equivalence between Utility Costs and the Utility of Money, Journal of Monetary Economics 17, pp. 271-291. http://dx.doi.org/10.1016/0304-3932(86)90032-2

Feldkord, Eva-Ulrike (2005), On the Relevance of Monetary Aggregates in Monetary Policy Models, HWWA Discussion Paper 317, May.

Fisher, Irving (1911), The Purchasing Power of Money, Macmillan.

Friedman, Milton (1956), The Quantity Theory of Money - A Restatement, in: M. Friedman, Studies in the Quantity Theory of Money, Chicago.

Friedman, Milton (2006), The Optimum Quantity of Money, in: M. Friedman, The Optimum Quantity of Money, AldineTransaction, New Brunswick / London.

Galí, Jordi (2002), Monetary Policy in the Early Years of EMU, Mimeo, Universitat Pompeu Fabra.

Gerberding, Christina, Franz Seitz \& Andreas Worms (2005). How the Bundesbank really conducted monetary policy, North American Journal of Economics and Finance 16, pp. 277292.

http://dx.doi.org/10.1016/j.najef.2005.05.003

Gerberding, Christina, Franz Seitz \& Andreas Worms (2009), Interest Rate Rules and Monetary Targeting: What are the links?, ROME Working Paper 2009-01, June.

Gerdesmeier, Dieter, Hans-Eggert Reimers \& Barbara Roffia (2010), Asset Price Misalignments and the Role of Money and Credit, International Finance 13, pp. 377-407. http://dx.doi.org/10.1111/j.1468-2362.2010.01272.x

Gertler, Mark \& Nobuhiro Kiyotaki (2011), Financial Intermediation and Credit Policy in Business Cycle Analysis, in: B. Friedman and M. Woodford (eds.), Handbook of Monetary Economics, Vol. 3A, North-Holland, pp. 547-599.

Gomis-Porqueras, Pedro \& Daniel Sanches (2013), Optimal Monetary Policy in a Model of Money and Credit, Journal of Money, Credit and Banking 45, pp. 701-729. http://dx.doi.org/10.1111/jmcb.12021

Goodfriend, Marvin (2005), Narrow Money, Broad Money, and the Transmission of Monetary Policy, in: J. Faust, A. Orphanides and D. Reifschneider (eds.), Models and Monetary Policy: Research in the Tradition of Dale Henderson, Richard Porter, and Peter Tinsley. Board of Governors of the Federal Reserve System.

Goodfriend, Marvin \& Robert G. King (1997), The New Neoclassical Synthesis and the Role of Monetary Policy, NBER Macroeconomics Annual 1997, Volume 12. http://dx.doi.org/10.2307/3585232

Goodhart, Charles A. E. (1975a), Monetary Relationships: A View from Threadneedle Street, in: Papers in Monetary Economics, Volume I, Reserve Bank of Australia.

Goodhart, Charles A. E. (1975b), Problems of Monetary Management: The UK Experience, in: Papers in Monetary Economics, Volume I, Reserve Bank of Australia.

Greiber, Claus \& Wolfgang Lemke (2005), Money Demand and Macroeconomic Uncertainty, Deutsche Bundesbank Discussion Paper 26-2005.

Greiber, Claus \& Ralph Setzer (2007), Money and Housing Evidence for the Euro Area and the US, Deutsche Bundesbank Discussion Paper 12-2007.

Gurley, John G. \& Edward S. Shaw (1960), Money in a Theory of Finance, The Brookings. Institution.
Hahm, Joon-Ho, Hyun Song Shin \& Kwanho Shin (2013), Noncore Bank Liabilities and Financial Vulnerability, Journal of Money, Credit and Banking 45(S), pp. 3-36.

Holman, Jill A. (1998), GMM Estimation of a Money-in-the-UtilityFunction Model: The Implications of Functional Forms, Journal of Money, Credit and Banking 30, pp. 679-698. http://dx.doi.org/10.2307/2601124

Howitt, Peter (2005), Beyond Search: Fiat Money in Organized Exchange, International Economic Review 46, pp. 405-429. http://dx.doi.org/10.1111/j.1468-2354.2005.00325.x

Ireland, Peter N. (2004a), The Liquidity Trap, the Real Balance Effect and the Friedman Rule, International Economic Review 46, pp. 1271-1301. http://dx.doi.org/10.1111/j.1468-2354.2005.00367.x

Ireland, Peter N. (2004b), Money's Role in the Monetary Business Cycle, Journal of Money, Credit and Banking 36, pp. 969983. http://dx.doi.org/10.1353/mcb.2005.0010

Kajanoja, Lauri (2003), Money as an Indicator Variable for Monetary Policy when Money Demand is Forward Looking, Bank of Finland Discussion Paper 9/2003.

Kim, Hyun Jeong, Hyun Song Shin \& Jaeho Yun (2012), Monetary Aggregates and the Central Bank's Financial Stability Mandate, Paper presented at the Federal Reserve conference "Central Banking: Before, During, and After the Crisis", March 23-24, 2012.

King, Mervyn (2002), No Money, no Inflation - The Role of Money in the Economy, Bank of England Quarterly Bulletin, Summer 2002, pp. 162-177.

Kiyotaki, Nobuhiro \& Randall Wright (1993), A Search-theoretic Approach to Monetary Economics, American Economic Review 83, pp. 63-77.

Kocherlakota, Narayana R. (1998), Money is Memory, Journal of Economic Theory 81, pp. 232-51. http://dx.doi.org/10.1006/jeth.1997.2357

Krueger, Malte (2012), Money: A market microstructure approach, Journal of Money, Credit and Banking 44, pp. 1245-1258. http://dx.doi.org/10.1111/j.1538-4616.2012.00530.x

Kydland, Finn E. \& Edward C. Prescott (1982), Time to Build and Aggregate Fluctuations, Econometrica 50, pp. 1345-1370. http://dx.doi.org/10.2307/1913386

Lagos, Ricardo (2006), Inside and Outside Money, Federal Reserve Bank of Minneapolis Research Department Staff Report No. 374, May.

Long, John B. \& Charles I. Plosser (1983), Real Business Cycles, Journal of Political Economy 91, pp. 36-69.

Lucas, Robert E. (1976), Econometric Policy Evaluation: A Critique, Carnegie-Rochester Conference Series on Public Policy 1 , pp. $19-46$. http://dx.doi.org/10.1016/S0167-2231(76)80003-6

Lucas, Robert E. (2000), Inflation and Welfare, Econometrica 68, pp 247-74. http://dx.doi.org/10.1111/1468-0262.00109

Mankiw, N. Gregory \& Ricardo A. M. R. Reis (2002), Sticky Information Versus Sticky Prices: A Proposal to Replace the New Keynesian Phillips Curve, Quarterly Journal of Economics 117, pp. 1295-1328. http://dx.doi.org/10.1162/003355302320935034

Marimon, Ramon, Juan Pablo Nicolini \& Pedro Teles (2012), Money Is an Experience Good: Competition and Trust in the Private Provision of Money, Federal Reserve Bank of Minneapolis Research Department Staff Report 467, July.

Matsuoka, Tarishi (2011), Monetary Policy and Banking Structure, Journal of Money, Credit and Banking 43, pp. 1109-1129. http://dx.doi.org/10.1111/j.1538-4616.2011.00419.x

McCallum, Bennett T. (2000), Theoretical Analysis Regarding a Zero Lower Bound on Nominal Interest Rates, Journal of Money, Credit and Banking 32, pp. 870-904. http://dx.doi.org/10.2307/2601148 
McCallum, Bennett T. (2001), Monetary Policy Analysis in Models Without Money, Federal Reserve Bank of St. Louis Review 83(4), pp. 145-160.

McCallum, Bennett T. (2002), Recent Developments in Monetary Policy Analysis: The Roles of Theory and Evidence, Federal Reserve Bank of Richmond Economic Quarterly, 88(1), pp. 67-96.

McCallum, Bennett T. \& Edward Nelson (2011), Money and Inflation: Some Critical Issues, in: B. Friedman and M. Woodford (eds.), Handbook of Monetary Economics, Vol. 3A, NorthHolland, pp. 97-153.

Minford, Patrick \& Naveen Srinivasan (2010), Determinacy in New Keynesian models: A role for money after all?, Cardiff Business School Working Paper E2009/21, September.

Minford, Patrick, Francesco Perugini \& Naveen Srinivasan (2002), Are Interest Rate Regressions Evidence of a Taylor Rule, Economics Letters 76, pp. 145-150. http://dx.doi.org/10.1016/S0165-1765(02)00034-4

Mishkin, Frederic S. (2010), Will Monetary Policy Become More of a Science?, in: V. Wieland (ed.), The Science and Practice of Monetary Policy Today, Springer, pp. 81-103. http://dx.doi.org/10.1007/978-3-642-02953-0 6

Nelson, Edward N. (2002), Direct Effects of Base Money on Aggregate Demand: Theory and evidence, Journal of Monetary Economics 49, pp. 687-708. http://dx.doi.org/10.1016/S0304-3932(02)00118-6

Nelson, Edward N. (2003), The Future of Monetary Aggregates in Monetary Policy Analysis, Journal of Monetary Economics 50, pp. 1029-59. http://dx.doi.org/10.1016/S0304-3932(03)00063-1

Nelson, Edward N. (2008), Why Money Growth Determines Inflation in the Long Run: Answering the Woodford Critique, Journal of Money, Credit and Banking 40, pp. 1791-1814. http://dx.doi.org/10.1111/j.1538-4616.2008.00183.x

Nosal, Ed \& Guillaume Rocheteau (2011), Money, Payments, and Liquidity, The MIT Press. http://dx.doi.org/10.7551/mitpress/9780262016285.001.0001

Orphanides, Athanasios (2003). The Quest for Prosperity Without Inflation, Journal of Monetary Economics 50, pp. 633-663. http://dx.doi.org/10.1016/S0304-3932(03)00028-X

Reichlin, Lucrezia (2006), Introduction, in: A. Beyer, and L. Reichlin (eds.), The Role of Money - Money and Monetary Policy in the $21^{\text {st }}$ Century, $4^{\text {th }}$ ECB Central Banking Conference, pp. 512.

Scharnagl, Michael, Christina Gerberding \& Franz Seitz (2010), Should Monetary Policy Respond to Money Growth? New Results for the Euro Area, International Finance 13, pp. 409441. http://dx.doi.org/10.1111/j.1468-2362.2010.01267.x

Schularick, Moritz \& Alan T. Taylor (2012), Credit Booms Gone Bust: Monetary Policy, Leverage Cycles, and Financial Crises, 1870-2008, American Economic Review 102, pp. 1029-1061. http://dx.doi.org/10.1257/aer.102.2.1029
Shi, Shouyong (1995), Money and Prices: A Model of Search and Bargaining, Journal of Economic Theory 67, pp. 467-496. http://dx.doi.org/10.1006/jeth.1995.1081

Shin, Hyun Song \& Kwanho Shin (2011), Procyclicality and Monetary Aggregates, NBER Working Paper 16836, February.

Söderström, Ulf (2005), Targeting Inflation with a Role for Money, Economica, 72, pp. 577-96. http://dx.doi.org/10.1111/j.1468-0335.2005.00433.x

Teles, Pedro \& Harald Uhlig (2010), Is Quantity Theory still Alive?, NBER Working Paper no. 16393, September.

Thornton, Daniel L. (2000), Money in a Theory of Exchange, Federal Reserve Bank of St. Louis Review, 82(1), January/February, pp. 35-60.

Thornton, Daniel L. (2014), Monetary Policy: Why Money Matters and Interest Rates Don't, Journal of Macroeconomics 40, pp. 202-213. http://dx.doi.org/10.1016/j.jmacro.2013.12.005

Tödter, Karl-Heinz (2002), Monetäre Indikatoren und geldpolitische Regeln im P-Stern-Modell, Review of Economics 53, pp. 210-243.

Trejos, Alberto \& Randall Wright (1995), Search, Bargaining, Money, and Prices, Journal of Political Economy 103, 118-141. http://dx.doi.org/10.1086/261978

Uhlig, Harald (2006), Comment on: Woodford, M., Does a "Two-Pillar Phillips Curve" justify a Two-Pillar Monetary Policy Strategy?, in: A. Beyer \& L. Reichlin (eds.), The Role of Money - Money and Monetary Policy in the $21^{\text {st }}$ Century, $4^{\text {th }}$ ECB Central Banking Conference, pp. 87-96.

Ullersma, Cees, Jan Marc Berk \& Bryan Chapple (2006), Money Rules, De Nederlandsche Bank Working Paper No. 096/2006, March.

Wallace, Neil (2011), The Mechanism Design Approach to Monetary Theory, in: B. Friedman and M. Woodford (eds.), Handbook of Monetary Economics, Vol. 3A, North-Holland, pp. 3-23.

Williamson, Stephen \& Randall Wright (2010), New Monetarist Economics: Methods, Federal Reserve Bank of St. Louis Review, 92(4), July/August, pp. 265-302.

Williamson, Stephen \& Randall Wright (2011), New Monetarist Economics: Models, in: B. Friedman and M. Woodford (eds.), Handbook of Monetary Economics, Vol. 3A, North-Holland, pp. 25-96.

Woodford, Michael (1998), Doing Without Money: Controlling Inflation in a Post-Monetary World, Review of Economic Dynamics 1, pp.173-219. http://dx.doi.org/10.1006/redy.1997.0006

Woodford, Michael (2003), Interest and Prices: Foundations of a Theory of Monetary Policy, Princeton University Press.

Woodford, Michael (2008), How Important is Money in the Conduct of Monetary Policy? Journal of Money, Credit and Banking 40, pp. 1561-1598.

http://dx.doi.org/10.1111/j.1538-4616.2008.00175.x

Zanetti, Francesco (2012), Banking and the Role of Money in the Business Cycle, Journal of Macroeconomics 34, pp. 87-94. http://dx.doi.org/10.1016/j.jmacro.2011.07.003

(C) 2014 Seitz and Schmidt; Licensee Lifescience Global.

This is an open access article licensed under the terms of the Creative Commons Attribution Non-Commercial License (http://creativecommons.org/licenses/by-nc/3.0/) which permits unrestricted, non-commercial use, distribution and reproduction in any medium, provided the work is properly cited. 